\title{
スケールアップモデルによる交互送液型マイクロリアクタの フローパターン特性の可視化実験*
}

\author{
冨士原 民雄*1, 大上浩*1, 牛島 達 夫*2 \\ 鬼頭 修已苂, 岡 本 秀 穂*3 \\ Visualization of Flow Pattern Characteristics in \\ Alternate Pumping Microreactor Using Scale-Up Model \\ Tamio FUJIWARA*4, Hiroshi OHUE, Tatsuo USHIJIMA, \\ Osami KITOH and Hideho OKAMOTO \\ ${ }^{* 4}$ Department of Mechanical Engineering, Musashi Institute of Technology, \\ 1-28-1 Tamazutsumi, Setagaya-ku, Tokyo, 158-8557 Japan
}

\begin{abstract}
In order to enhance the mixing and reaction yield in a microreator, an alternate pumping method has been investigated. As the visualization results of the flow patterns generated by the alternate pumping in several types of micro channel, the flow patterns were classified into five categories depending on the pumping conditions, which are the Reynolds number and the non-dimensional infusion time that are defined by the infusion flow parameters. One of the flow patterns which we observed is a layered structure and is able to contribute to enhancing the diffusion mixing, because the molecular diffusion time is proportional to the square of the diffusion length and the thickness of each layer in the layered structure can be taken thinner than the width of micro channels, which is the diffusion mixing length in the case of the convestional concurrent pumping. The most appropriate channel for creating the layered structure is a cross-shaped channel consisting of two inlets and two mixing channel. It is confirmed that the thickness of each layer is less than one-tenth of the mixing channel width, i.e. the mixing time is reduced to less than one-hundredth of that in the concurrent pumping with the same dimension.
\end{abstract}

Key Words: Flow Visualization, Micromechanics, Fluidics, Chemical Reaction, Chemical Engineering Equipment, Microfluidics, Microreactor, Micromixer

\section{は じめ に}

流体工学では, $\mu$ TAS, MEMS, ラボ・オン・チッ プ等の技術がマイクロ・フルイディクスと呼ばれる新 分野として注目されつつあり，マイクロリアクタある

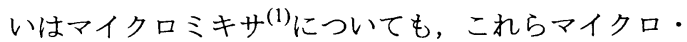
フルイディクスの一つとして研究がなされている(2)(3). また, マイクロ・フルイディクスの研究手法として, マイクロ PIV 等の顕微鏡による可視化技術が盛んに利 用されており, それらの研究成果に対する期待は高い.

マイクロリアクタとは幅が $1 \sim 100 \mu \mathrm{m}$ オーダのマ イクロ流路内で, 複数の物質を混合・反応させる装置 であり，本研究では二種の液体を混合・反応させる場 合を取り扱う。図 1 に示すような $\mathrm{T}$ 字型マイクロ流路 を用い，二方向から二種の液体を一つの混合流路に注 入する場合, 流路内の流れはレイノルズ数が小さく層

* 原稿受付 2005 年 8 月 10 日.

*1 正員, 武藏工業大学工学部(西158-8557 東京都世田谷区玉 堤 1-28-1).

*2 正員, 名古屋工業大学工学部 (- 466-8555 名古屋市昭和区 御器所町).

*3 京都大学大学院工学研究科 $(-615-8530$ 京都市西京区京都 大学桂).

E-mail : tfujiwa@sc.musashi-tech.ac.jp
流となるため, 乱流による物質の混合はなく，物質は 分子拡散のみによって混合される. したがって, 均質 な混合による反応収率の向上と反応時間の短縮ができ るほか, 試液量が少なく環境負荷が小さいことなどが, マイクロリアクタの利点として挙げられる.

今日のマイクロリアクタ技術では，さらなる混合・ 反応時間の短縮と反応収率の向上が課題となっている. 混合・反応時間が長い場合, 流路長が短いか流速（流 量）が大きいと反応収率の低下を招く.よって, 流体の 流路内滞留時間を長くして十分な混合・ 反応時間を担 保するためには，流路を長くするかもしくは流速（流 量）を小さくするかしなければならないが，流路長に は加工上の制約があり, 逆に流量を小さくすると生成 物の生産量に制限が生じ工学上のデメリットが生じる.

従来の手法では二種の溶液を同時に混合流路に注入 していたが, 最近では注入圧力に変動を持たせるなど の方法による, 動的な混合促進が試みられている. そ の中でも, Okamoto $ら^{(4)}$ や Kaneko $ら^{(5)}$ は, 溶液を交 互に送液する方法を提案している. 


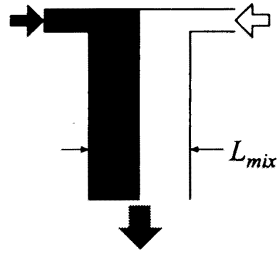

(a) Concurrent

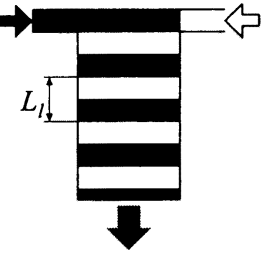

(b) Alternate
Fig. 1 Expected flow pattern generated by alternate pumping.

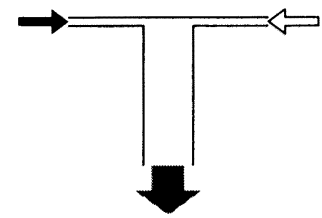

(a) ' $T$ '-shaped channel

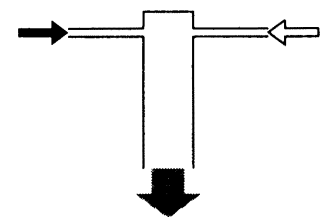

(b) ' $t$ '-shaped channel

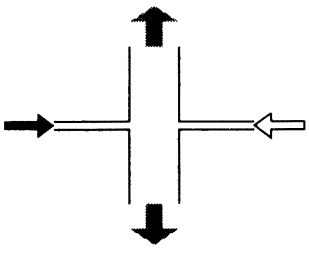

(c) Cross-shaped channel

Fig. 2 Three channel shapes.

分子拡散による混合に必要な時間 $T$ は分子拡散係数 $\alpha$ に反比例し, 混合距離 $L$ の二乗に比例する.

$$
T \propto \frac{L^{2}}{\alpha}
$$

$\alpha$ は物性值であるので， $T$ を小さくするには $L$ をさ くするしかない，従来の同時送液では，図 1 (a)のよ うに混合流路内で溶液は二分され, 拡散混合距離は混 合流路幅 $L_{m i x}$ をなる．よって， $T$ を小さくするには $L_{m i x}$ を縮小すればよいが，それには加工上の制約が生 じる，一方，交互送液により図1(b) のような薄い層 構造が流路内に形成されるとするならば, 拡散混合距 離は層の厚さ $L_{l}$ となり, 送液条件によって $L_{l}$ を $L_{\text {mix }}$ よりも小さくして混合時間 $T$ を短縮することが可能と なる.

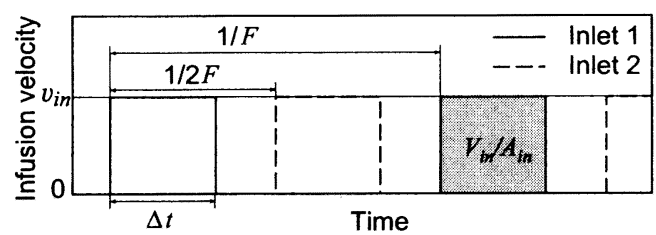

Fig. 3 Pumping time sequence.

しかし，混合流路内に形成されるフローパターンと 交互送液条件の関係についてはまだ明らかになってお らず，混合流路幅よりも薄い層構造が実際に作れるか どうかは不明である。そこで，著者らは交互送液によ るフローパターンの可視化実験を行い, その結果の一 部を報告した ${ }^{(6)}$. 本報では，流路形状についても層構 造形成を容易にするため新たに考案したものを含めて 三種類の形状のものを用い, さらに詳細な実験結果よ りフローパターン特性を解明し, マイクロリアクタと しての流路形状を含む交互送液条件の最適化のための 資料を得ることを目的とする.

一般的な寸法のマイクロリアクタの流路において可 視化を行うには高価な撮影機材を要し，また想定され る交互送液の時間スケールが小さく撮影画像の十分な 時間分解能を得ることが困難であった。 そこで本実験 では, レイノルズ相似則に基づくスケールアップモデ ルを用いることにより，比較的容易な可視化を可能と した.

\section{1. 主な 記 号}

流路寸法

$L_{\text {in }}$ : 注入流路幅

$L_{m i x}$ : 混合流路幅 $\left(=L_{i n} \times 10\right)$

$d$ : 流路深さ $\left(=L_{i n}\right)$

交互送液条件

$$
\begin{array}{ll}
v_{i n} & : \text { 注入平均速度 } \\
\Delta t & : \text { 注入時間 } \\
F & : \text { 送液周波数 } \\
V_{i n} & : \text { 注入体積 }
\end{array}
$$

\section{無次元量}

$R e$ : レイノルズ数

$\Delta t^{*}$ : 無次元注入時間

$F^{*}$ : 無次元周波数

その他

$v$ : 動粘度

$L_{l}$ : 平均層厚さ 

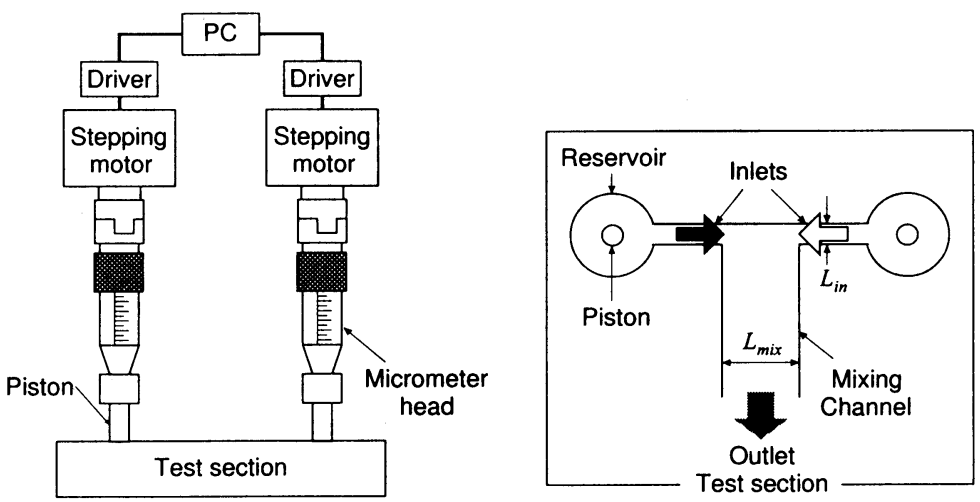

Fig. 4 Schematic diagram of the experimental apparatus.

\section{2. 支配パラメータの導出}

本実験では図 2 に示寸三種の形状の流路について実 験を行った. 各流路において, 注入流路の幅を $L_{i n}$, 混 合流路の幅を $L_{m i x}$, 流路哚さを $d$ とする.

交互送液は図 3 に示すタイムシーケンスで行った. 一回あたりの送液は注入流路断面平均速度 $v_{i n}$ が一定 でステップ的に行われ，加減速に要する時間は無視で きるものとする．交互送液は注入時間 $\Delta t$ の送液を周 波数 $F$ で繰り返す．ただし，送液時間のオーバーラッ プはないものとする. また, 一回あたりの注入体積 $V_{i n}$ は, 注入流路断面積 $A_{i n}=L_{i n} d$ を用い,

$$
V_{\text {in }}=v_{\text {in }} \Delta t A_{\text {in }}
$$

と表される.

本実験で取り扱う流れを支配する独立変数は, $L_{i n}$, $L_{\text {mix }}, d, v_{i n}, \Delta t, F, v$ である. これらの中で $L_{i n}, L_{m i x}$ については, 薄い層構造を実現するためには $L_{\text {mix }}$ に 対して $L_{\text {in }}$ がなるべく小さい方が良いが，実際のマ イクロリアクタ用チャネル加工上の限界を考虑し， $L_{\text {mix }}=L_{i n} \times 10$ とした. また, 流路深さについても加 工上の制約を考慮し， $d=L_{i n}$ と設定した. 以上より $L_{m i x}$ と $d$ は $L_{i n}$ の従属変数として扱える. よって, 残 りの五つの独立変数から, 流体注入時の注入流路内流 れに関する変数 $L_{\text {in }}$ と $v_{\text {in }}$ を代表変数に選ぶと, $v, \Delta t$, $F$ よりレイノルズ数 $R e$, 無次元注入時間 $\Delta t^{*}$, 無次元 周波数 $F^{*}$ が以下のように得られる.

$$
\begin{aligned}
R e & \equiv \frac{L_{i n} v_{i n}}{v} \\
\Delta t^{*} & \equiv \frac{\Delta t v_{i n}}{L_{i n}} \\
F^{*} & \equiv \frac{F L_{i n}}{v_{i n}}
\end{aligned}
$$

$\Delta t^{*}$ は式 (2), (4)より

$$
\Delta t^{*}=\frac{\Delta t V_{i n}}{L_{i n} \Delta t A_{\text {in }}}=\frac{V_{\text {in }}}{L_{\text {in }}^{2} d}
$$

とも表され， $\Delta t^{*}$ は注入体積 $V_{i n}$ に比例するパラメー タでもあることが分かる.

以上より，相似形状流路内のフローパターンは三つ のパラメータ $R e, \Delta t^{*}, F^{*}$ によって規定されることが 示された. 本研究では, 三次元パラメータ $\left(R e, \Delta t^{*}, F^{*}\right)$ 空間におけるフローパターンの系統的変化を可視化実 験により調査し, 交互送液法によるマイクロリアクタ の可能性とそのための最適条件を探ることを主な目的 とする. なお，注入流路幅 $L_{i n}$ を $10 \sim 150 \mu \mathrm{m}$, 注入速 度 $v_{\text {in }}$ を最大 $1 \mathrm{~m} / \mathrm{s}$ オーダと想定し, 動粘度は $v \sim 10^{-6}$ $\mathrm{m}^{2} / \mathrm{s}$ （水と同程度を想定）を仮定して，レイノルズ数 $R e$ の調查範囲を最大 150 程度とした。

\section{3. 実験装置および方法}

図 4 に実験装置概略を示す，試験部には二つの注入 流路および混合流路からなるマイクロ流路があり，注 入流路上流にはリザーバーがある.リザーバーにはピ ストンが挿入されており，このピストンをリザーバー 一押し込むことにより送液する．ピストンの駆動はマ イクロメータヘッドとステッピングモータで構成され る送り装置によって行われ，ステッピングモータの動 作はPCによって制御される.

マイクロ流路形状は, 図2 に示すコ種について実験 を行った. T字型は現在最も一般的なマイクロリアク 夕流路の形状の一つであり，二つの注入流路と一つの 混合流路が直交している. $\mathrm{t}$ 字型は $\mathrm{T}$ 字型の混合流路 反対側に窪みを設けたものであり，十字型では混合流 路と出口を反対側にもう一つ設けた。 なお，十字型は 二つの混合流路内での圧力勾配が異なると両者におけ 
る流量が異なるため, 同流量になるように流動抵抗を 調整した.

全ての流路は，可視化を容易にするため前章で示し たパラメータがレイノルズの相似性を満たすスケール アップモデルを用いた. スケールアップモデルにおけ る変数には’（プライム）をつけて表すとすると、レ イノルズ数が等しい場合には,

$$
R e=\frac{L_{i n} v_{i n}}{v}=\frac{L_{i n}^{\prime} v_{i n}^{\prime}}{v^{\prime}}
$$

が成立する. 供試流体としていずれも水を用いるので, 動粘度は等しく $v=v^{\prime}$ となり， $L_{i n} v_{i n}=L_{i n}^{\prime} v_{i n}^{\prime}$ を得る. ここで, スケールアップ比を $\beta \equiv L_{\text {in }}^{\prime} / L_{\text {in }}$ とおくと, 速 度スケールの比が

$$
\frac{v_{i n}^{\prime}}{v_{\text {in }}}=\frac{1}{\beta}
$$

となる，一方, 時間 $\Delta t$ に対しては,

$$
\begin{aligned}
\Delta t^{*} & =\Delta t \frac{v_{i n}}{L_{i n}}=\Delta t^{\prime} \frac{v_{i n}^{\prime}}{L_{i n}^{\prime}} \\
\therefore \frac{\Delta t^{\prime}}{\Delta t} & =\frac{v_{i n}}{v_{i n}^{\prime}} \frac{L_{i n}^{\prime}}{L_{i n}}=\beta^{2}
\end{aligned}
$$

の関係が成立する. 本実験で用いたスケールアップモ デルでは, 流路製作が容易で, 比較的安価な機材によ る撮影を可能とするため, $L_{i n}^{\prime}=0.4 \mathrm{~mm}, L_{\text {mix }}^{\prime}=4 \mathrm{~mm}$ と設定した. 仮にマイクロリアクタの注入流路寸法を $L_{i n}=50 \mu \mathrm{m}$ とすれば, $\beta=8$ で時間は 64 倍の拡大と なり, フローパターンの時間変化を十分な時間分解能 で撮影することができる

\section{4. 実験結果および考察}

$4 \cdot 1$ フローパターンの分類 本実験で観察され た五つのフローパターンについて，それぞれの典型的 な可視化画像を図 5 に示す. なお, 各画像は左側から の注入が終わった瞬間のものである. フローパターン は注入流体が注入方向にどこまで到達したかによって 変化し, 送液条件を連続的に変化させた場合, フロー パターンは次の A から E の間を連続的に変化する.

A 注入流体は混合流路中央までしか到達せず, 交互 送液の影響が現れず，平らな界面が形成される.

$\mathrm{B}$ 流体はやや哚くまで到達し, 交互送液の影響が現 れ, 界面が波型になる.

C さらに流体が深く到達し, 混合流路主流の速度分 布によって波型界面が放物線状にゆがむ.

$\mathrm{D}$ 流体が対壁面に到達し, 混合流路に層が形成さ れる.

$\mathrm{E}$ 流体が対壁側に偏り, 両流体が入れ替わって分離 される.
以上の五つのパターンで本実験の目的である層構造 を混合流路に形成するのは, パターンDのみである.

$\mathrm{T}$ 字型について注入流体の動きを観察すると, 上壁 に接した流体が粘性せん断力によって减速・静止する ため，いずれのパターンにおいても流体がもう一方の 流体に交換されない領域が注入流路近傍に存在する. その結果, 流体が持つ注入方向モーメントを失い, 主 流が注入方向から混合流路方向へ曲がり, 注入流体が 対壁に到達しにくくなる。

上壁による摩擦の影響をなくすために等みを設けた $\mathrm{t}$ 字型流路では, $\mathrm{T}$ 字型に比べると注入方向モーメン トの損失が軽減され，注入流体が対壁へ到達しやすく なる. しかし, 窪みの中の静止流体からのせん断力は 存在し, 注入流体の進行方向が混合流路方向一転換し, 流体が交換されない領域が存在する.

そこで，注入流体の方向転換をなくすため，十字型 では注入流路中心軸に対して対称な流れになるよう, 二方向に混合流路を設けた. その結果, 図からわかる ように，流体は進行方向を転換することなく注入され， 容易にパターンD を形成することが出来た.

図6に十字型流路におけるパターンDの模式図を示 す. 層の形状を見ると, 主流の進行と共に壁面摩擦に よって界面が放物線状に引き伸ばされ（ストレッチ効 果), 層の厚さは下流へ進むほど薄くなっていく. 本 研究の目的である薄い層構造の形成の観点からは, こ のストレッチ効果は混合促進に寄与する.

4.2 フローパターン分布 送液条件は三つの無 次元数 $R e, \Delta t^{*}, F^{*}$ によって規定されるが，これらの 内レイノルズ数 $R e$ と無次元注入時間 $\Delta t^{*}$ よりなる二次 元空間におけるフローパターンの分布図を図 7 に示す. ただし, 無次元周波数については $F^{*}=0.001 \sim 0.05$ で 実験を行い, すべての結果を区別せずに図 7 に示した. この結果, フローパターンが $F^{*}$ に依存せず, 二次元 $\left(R e-\Delta t^{*}\right)$ 空間によって整理できることが分かった。 その理由を以下に述べる.

周波数は注入時間と送液停止時間の和の逆数として 与えられるので, 注入時間が与えられる場合, 周波数 は停止時間のみの関数と考えられる. 停止時間中の流 体の運動に着目すると, 注入流路より混合流路に注入 された流体は, 注入が終了し次に反対側から流体が注 入されるまでの停止時間中も慣性により運動を続ける が, 運動は粘性によって時間と共に減衰する. 今回の 条件ではレイノルズ数が小さく粘性力の影響が強く運 動の減衰が早いので, 停止時間中の運動の影響は無視 できる. したがって, フローパターンは送液停止時間 の長さには依存せず, 注入時間が与えられる場合には 


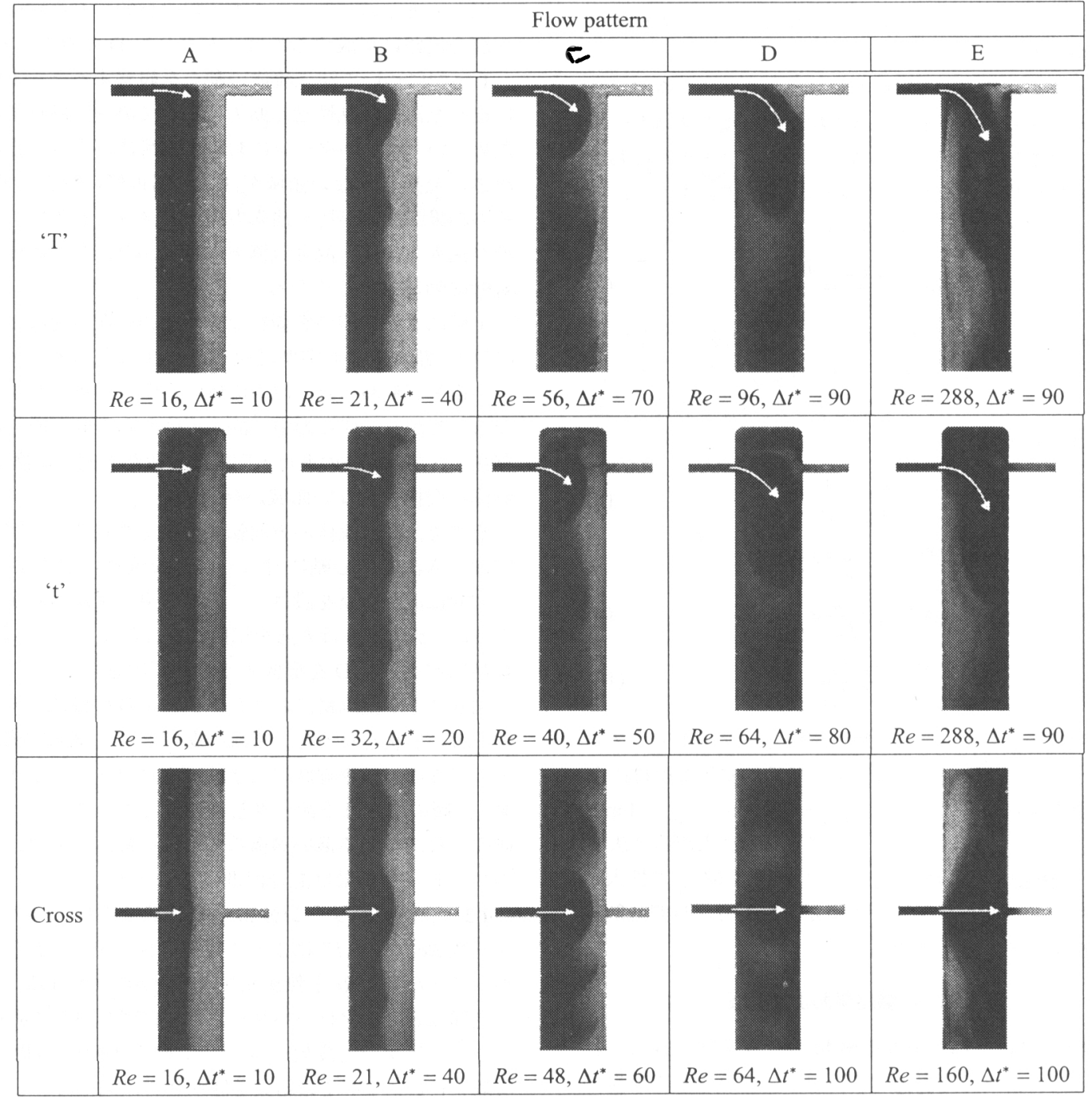

Fig. 5 Visualization results of flow patterns when the infusion from the left inlet has been finished.

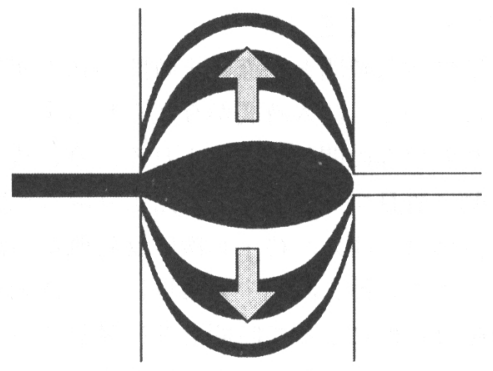

Fig. 6 Schematic diagram of Pattern D in the crossshaped channel.
周波数にも依存しない.

その結果, 流体の注入速度と注入時閒によって注入 流体がどこまで到達するかによってのみフローパター ンが決まる. 式(3)，(4)に示したように, Reと $\Delta t^{*}$ は 流体注入時の注入流路内流れに関するパラメータより 定義される無次元量であることから，フローパターン 分布は $R e-\Delta t^{*}$ 二次元空間内で表すことが出来る.

二次元空間におけるフローパターン特性は, Re と $\Delta t^{*}$ が大きいほど，パターン A から E 八変化する. 式 (3), (4), (6) が示寸とおり, Reが大きい場合には注入 速度 $v_{\text {in }}$ が大きく注入流体の持つ慣性力が粘性力に対 して大きくなり， $\Delta t^{*}$ が大きい場合には注入時間 $\Delta t お$ 


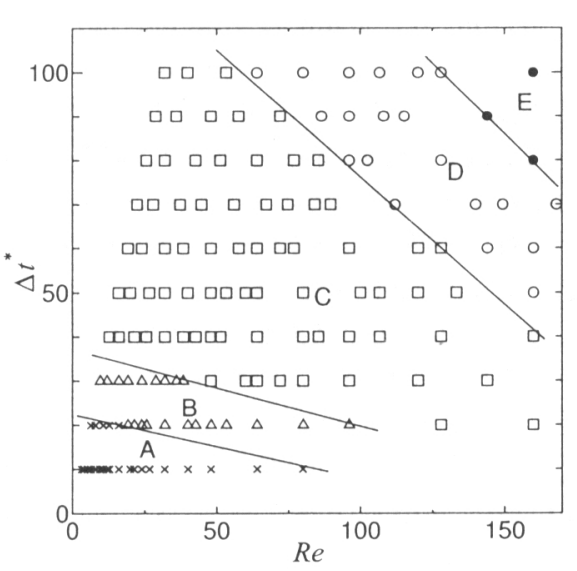

(a) ' $T$ '-shaped channel

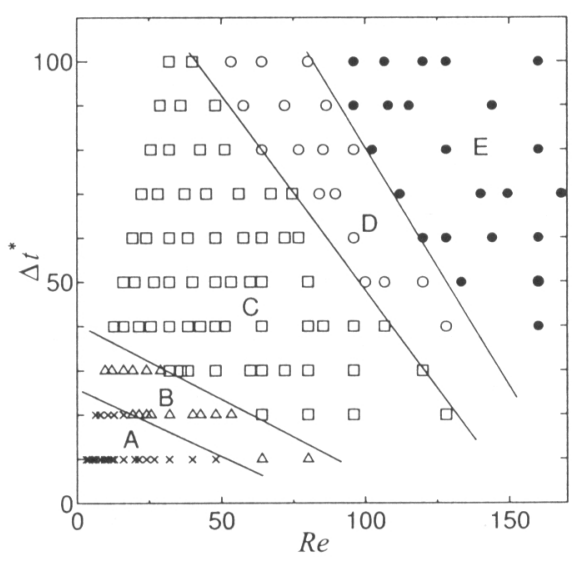

(b) 't'-shaped channel

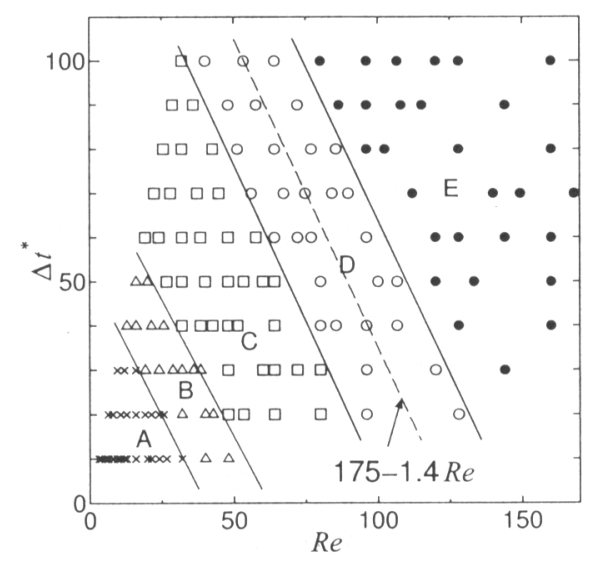

(c) Cross-shaped channel

Fig. 7 Flow pattern maps in $R e-\Delta t^{*}$ space.
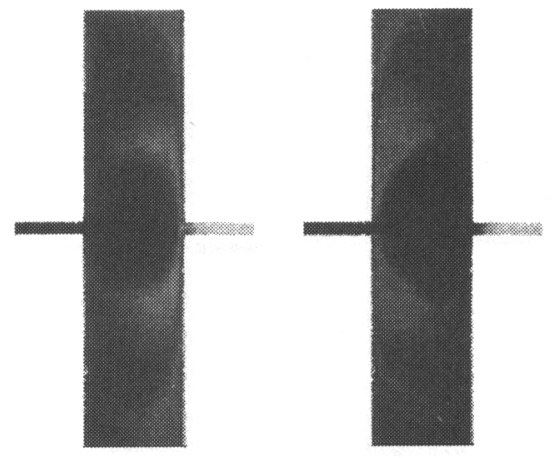

Fig. 8 Figures of Pattern D under the conditions closed to the boundary of Pattern C-D or D-E.

よび注入体積 $V_{\text {in }}$ が大きくなることから，注入流体が より奥へ侵入する。図7 はこの特性を表している.

4.3 送液条件の最適化本研究の目的である薄 い層構造を混合流路内に形成するための条件を導く. 層構造となるフローパターンはDである。パターン D のときの層の平均厚さ $L_{l}$ は, $\mathrm{T}$ 字型および $\mathrm{t}$ 字型の場 合は,

$$
L_{l}=\frac{V_{\text {in }}}{L_{\text {mix }} d}
$$

十字型では注入流体が二方に分かれるので,

$$
L_{l}=\frac{V_{\text {in }}}{2 L_{\text {mix }} d}
$$

と表され，式 (6) より $V_{i n}$ は $\Delta t^{*}$ に比例するので，平 均層厚さ $L_{l}$ は $\Delta t^{*}$ に比例する. 図 7 で $\Delta t^{*}$ がより小さ い領域でパターン D が形成されるのは, 十字型流路 の場合である.しかも, 式(12)に示したように, 同じ $V_{\text {in }}$ でも $\mathrm{T}$ 字型と $\mathrm{t}$ 字型に比べて層の厚さは半分にな るので, 薄い層構造を形成するのに最も適した流路形 状は十字型となる。

図 8 に示寸ように, パターン D でも, パターンC や $\mathrm{E}$ の領域に近い条件では, 層構造を形成しながらも 互いの層が左右に偏った形状となる，理想的な左右で ほぼ均一な層構造が形成される条件は, 図 7 (c) の破 線で示した

$$
\Delta t^{*}=175-1.4 R e
$$

となる。

次に, 十字型流路で理想的なパターン D が形成さ れる時, 平均層厚さ $L_{l}$ の混合流路幅 $L_{m i x}$ に対する比 は, 式(6), (12)より

$$
\frac{L_{l}}{L_{\text {mix }}}=\frac{1}{2} \frac{L_{\text {in }}^{2} d}{L_{\text {mix }}^{2} d} \Delta t^{*}=\frac{1}{2} \frac{L_{\text {in }}^{2}}{L_{\text {mix }}^{2}} \Delta t^{*}
$$




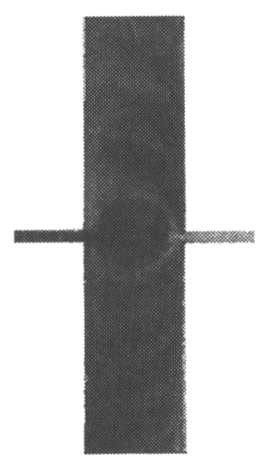

(a)

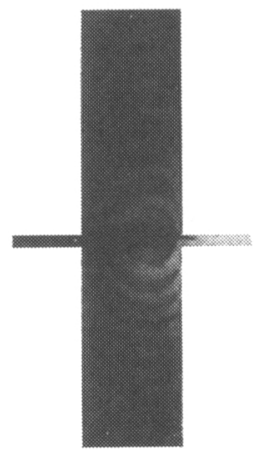

(b)
Fig. 9 Flow pattern of the thin layers structure in the cases of (a) $\operatorname{Re}=96, \Delta t^{+}=30$ and (b) $\operatorname{Re}=110$, $\Delta t^{+}=20$.

と書ける. 同時送液よりも混合が促進される条件は, 層 厚さが混合流路幅よりも小さい, 寸なわち $L_{l} / L_{m i x}<1$ となることであるので,

$$
\Delta t^{*}<2 \frac{L_{m i x}^{2}}{L_{\text {in }}^{2}}
$$

となる。

以上より，交互送液による混合促進の条件は，式(13) と式 (15) を満足することである.

次に，実機での送液条件を算出する. 注入時間 $\Delta t$ は, 式(3) を式(4)に代入し,

$$
\begin{aligned}
\Delta t^{*} & =\frac{v \Delta t R e}{L_{\text {in }}^{2}} \\
\therefore \Delta t & =\frac{L_{\text {in }}^{2} \Delta t^{*}}{v R e}
\end{aligned}
$$

と表される。また, 注入速度 $v_{i n}$ は, 式 (3)より,

$$
v_{\text {in }}=\frac{v R e}{L_{\text {in }}}
$$

となる。

今回実験を行った条件では $\Delta t^{*}$ の最小值は 20 であ った. 図 $9 に R e=96, \Delta t^{*}=30$ の場合と $R e=110$, $\Delta t^{*}=20$ の場合のフローパターンを示寸。この結果よ り, 薄い層構造が形成され, 図 5 と比較すると二種の 溶液の層の境界が不明確になっており, 注入直後から 混合されつつあることが確かめられる。また，各層の 厚さはほぼ一様であり, 注入流路近くの層でも最大厚 さが平均厚さ $L_{1}$ と同程度とみなせ，下流においては 主流のストレッチ効果により, 実質的な層の厚さはさ らに小さくなる。

式(13)より $\Delta t^{*}=20$ の場合の最適なレイノルズ数 は $R e=110$ となる. また, 想定条件より $L_{i n}=50 \mu \mathrm{m}$,
$L_{\text {mix }}=500 \mu \mathrm{m}, d=50 \mu \mathrm{m}, \quad v=1 \times 10^{-6} \mathrm{~m}^{2} / \mathrm{s}$ とする. これらの条件を式 (14), (17), (18) に代入すると, 層 厚さ比 $L_{l} / L_{m i x}=1 / 10$, 注入時間 $\Delta t=0.45 \mathrm{~ms}$, 注入速 度 $v_{\text {in }}=2.2 \mathrm{~m} / \mathrm{s}$ （流量に換算すると $5.5 \mu \mathrm{l} / \mathrm{s}$ ） となる 実質的な層の厚さは平均層厚さよりも小さくなること から, 式 (1)より同時送液に比べて交互送液により混 合時間が $1 / 100$ 末満に短縮される。

4.4 チャネル寸法の効果とレイノルズ相似則につ いて 今回の実験結果より得られたフローパター ン特性は，レイノルズ相似則の仮定が正しければ実際 のマイクロリアクタでも成立する。しかし, 完全相似 が満足出来ない要因によってフローパターン特性が変 化する可能性はあるので, チャネル寸法や流体の動粘 度を変化させてレイノルズの相似則を検証する必要が ある、また, 今回の実験は, 三つのチャネル寸法 $L_{i n}$, $L_{m i x}, d$ は全て同じ条件で行ったが, これらの寸法比 が異なった場合にはフローパターン特性が変化するこ とが予想される。

これらの点については今後の更なる実験を行い, 続 報として報告する予定である。

\section{おわり に}

マイクロリアクタの交互送液による混合促進条件の 最適化のため, フローパターン特性を可視化により明 らかにした。フローパターンは注入流体の注入方向へ の侵入の度合いによって変化し, パターン A から E一 連続的に変化する. 混合促進に適した層構造となるつ ローパターンはD D である。フローパターンは, 流体 注入時の注入流路内流れに関するパラメータで定義さ れるレイノルズ数 $R e$ と無次元注入時間 $\Delta t^{*}$ にって 整理され，Reと $\Delta t^{*}$ が大きいほど $\mathrm{A} か ら \mathrm{E}$ に変化す る。交互送液により最も薄い層構造を作りやすい流路 形状は十字型であり, パターン Dの時の平均層厚さは $\Delta t^{*}$ に比例する。これまでに十字型流路でパターン D を形成されることが確認できた $\Delta t^{*}$ の最小值は 20 で, この場合 $R e$ は 110 とすれば理想的な層構造が形成さ れ，実質的な層厚さが混合流路幅の $1 / 10$ 末満になり， このときの混合時間は同時送液に比べて $1 / 100$ 末満と なる。

\section{文献}

(1) Ehrfeld, W., Hessel, V. \& Loewe, H., Micro-reactors New Technology for Modern Chemistry, Wiley/VCH, New York/Weinheim, (2000)

(2) Tan, C. K. L., Tracey, M. C., Davis, J. B. and Johnston, I. D., Continuously variable mixing-ratio micromixer with elastomer valves, "J. Micromech. Microeng.", Vol. 15, (2005), pp. 1885-1893. 
(3) Horiuchi, K., Obata, H. \& Matsudaira, Y., Evaluation of Micro Mixer Performance with Multiple Visualization Technique, Proceedings of JSME Fluid Engineering Conference 2004, (2004), 206.

(4) Okamoto, H., Ushijima, T. \& Kitoh, O., New methods for increasing productivity by using microreactors of planar pumping and alternating pumping types, "Chem. Eng. J.", Vol. 101, (2004), pp.57-63.

(5) Kaneko, T., Izawa, S, Xiong, A. K. \& Fukunishi, Y., Mixing enhancement of two liquids by active control in a millimeter-scale channel flow, "Proc. 10th Asian Cong. Fluid Mech.", (2004), A19.

(6) Fujiwara, T., Ushijima, T., Okamoto, H., Kitoh, O. \& Ohue, H., Characteristics of Flow Pattern in Alternative Pumping Microreactor, "Proc. 6th KSME-JSME Thermal and Fluids Eng. Con.”, (2005), KF02. 